\title{
Growth, reproduction and ontogenetic migration of the greasyback shrimp Metapenaeus ensis in Osaka Bay, Japan
}

\author{
HiroyUKi ARIYAMA ${ }^{1,2 *} \&$ MASAKI SANO ${ }^{1}$ \\ ${ }^{1}$ Marine Fisheries Research Center, Research Institute of Environment, Agriculture and Fisheries, Osaka Prefecture, \\ Tanagawa, Misaki, Osaka 599-0311, Japan \\ 2 Present address: Osaka Museum of Natural History, 1-23 Nagai Park, Higashi-Sumiyoshi-ku, Osaka 546-0034, Japan
}

Received 5 November 2013; Accepted 2 February 2015

\begin{abstract}
To clarify the growth, reproduction and ontogenetic migration of Metapenaeus ensis, 96,898 individuals (6-175 mm in body length, BL) were collected from five areas in Osaka Bay. Larval settlement was estimated to occur from June or July to October in the Yodo River mouth. Juveniles grew there and migrated to the innermost area of the bay, and then to the deeper areas as they grew. Growth of females showed a good approximation to a seasonally fluctuating von Bertalanffy equation, with a size-frequency distribution suggesting the presence of 2 or 3 cohorts per year. Body length of females attained $35-125 \mathrm{~mm}$ in the first winter and $105-150 \mathrm{~mm}$ in the second, and their life span is estimated to be about two years. Their reproductive season was mainly from June or July to September in the second year (ca. 1 year old), and mainly July in the third year (ca. 2 years old). The broad variation in the size range of reproducible females (BL 76-168 mm) suggests indeterminate growth. Males were smaller than females with overlapping cohorts but their life cycle appears to be similar to that of females.
\end{abstract}

Key words: greasyback shrimp, growth, Metapenaeus ensis, migration, reproduction

\section{Introduction}

The greasyback shrimp Metapenaeus ensis (de Haan) is widely distributed in the Indo-West Pacific, from Sri Lanka and India, through Australia and Southeast Asia, to Japan, and is a commercially important shrimp in many countries (Holthuis 1980, Hayashi 1992). The life history of this shrimp has been studied at many localities: nursery for juveniles and maturity in Australia (e.g. Courtney et al. 1989, Crocos et al. 2001); population ecology in a Vietnamese river (Viet \& Sakuramoto 2013); maturation, growth and recruitment in Hong Kong (Cheung 1964, Chu et al. 1993, Leung 1997); and maturation, migration and nursery in Taiwan (Su 1988, Su \& Liao 1994). Especially in Japan, many ecological studies on this shrimp have been carried out at various localities: Mikawa Bay and Ise Bay (Aichi Prefectural Fisheries Experimental Station 1942); Lake Naka-umi and Lake Shinji (Ota 1949); the Seto Inland Sea [Kii Channel (Ueta et al. 1993); Osaka Bay (Abe et al.

\footnotetext{
*Corresponding author: Hiroyuki Ariyama; E-mail, ariyamah@rinku. zaq.ne.jp
}

1995, Yamochi et al. 1995, Ariyama et al. 1997); Bisanseto (Yasuda 1956); Suo-nada (e.g. Yatuyanagi \& Maekawa 1956, Ishida et al. 1985, Tokuda et al. 1997, Katayama et al. 2001)]; Tosa Bay (Kochi District Fisheries Improvement Council \& Kochi Prefectural Kochi Fisheries Guidance Office 1971, Sakaji \& Komatsu 2004); and the Ariake Sea (Ikematsu 1959). Although these studies have examined features such as growth, maturation, migration and life span, such life-history characteristics differed greatly among localities. Moreover, there remains a problem with the analysis of growth: (1) detailed studies on the juveniles have been carried out, only in Osaka Bay and Fukuoka Prefecture (Suo-nada); (2) most of the studies on growth used data only of either juveniles in the nursery or adults at the fishing ground; and (3) even if data for both juveniles and adults were used, the number examined was relatively small and many cohorts overlapped (Katayama et al. 2001). Therefore, the estimated growth may be incorrect.

Metapenaeus ensis has been studied in Osaka Bay since 1989. Yamochi et al. (1995) reported that the brackish area of the Yodo River mouth is a nursery area for this shrimp, 
which has a high tolerance to the ambient hypoxic conditions. Ariyama \& Sano (2000) conducted release experiments of artificially reared $M$. ensis in the Yodo River mouth. Subsequently, decline of this population has been monitored by collecting a large number of individuals at various locations in Osaka Bay. The present paper considers the analysis of these data using recently developed statistical methods (Aizawa \& Takiguchi 1999, Gorie 2001) and reports on the growth of $M$. ensis throughout its life span, its reproduction and ontogenetic migration within Osaka Bay.

\section{Materials and Methods}

\section{Sampling}

Metapenaeus ensis individuals were collected from five areas in Osaka Bay from July, 1992 to March, 2000. Table 1 and Fig. 1 show a synopsis of the samplings and sampling areas, respectively. In the Yodo River mouth, two types of gear were used for sampling (Ariyama 2004). The pump sled $(80$ or $90 \mathrm{~cm}$ wide, $30 \mathrm{~cm}$ high, mesh size 3.5 or $5.0 \mathrm{~mm}$ ) was operated in deeper parts throughout the sampling period. Both sides of the sled have a sliding plate
$15 \mathrm{~cm}$ wide. Metal pipe with many holes was also provided. Water from a small pump flows through holes in the metal pipe, on the underside near the sled mouth, to disturb the bottom sediment. It was towed along the bottom of the center line of the river by a small fishing boat for $5 \mathrm{~min}$ at a speed of $40-60 \mathrm{~m} \mathrm{~min}^{-1}$. The small sled $(50 \mathrm{~cm}$ wide, $20 \mathrm{~cm}$ high, mesh size $13.8 \mathrm{~mm}$ ) was operated only from 1995 to 1997 in shallower parts. Both sides of the sled have a sliding plate $10 \mathrm{~cm}$ wide and 19 claws (each $10 \mathrm{~cm}$ long) to dig up sediment in front of the sled mouth. It was towed $50 \mathrm{~m}$ by two men towards the riverside.

Samples were also taken in the innermost area of Osaka Bay (where commercial trawling is prohibited for preservation of fisheries resources and traffic safety; Fig. 1), using an Ishigeta dredge, typical trawling gear in Osaka Bay $(156 \mathrm{~cm}$ wide, $27 \mathrm{~cm}$ high and ca. $3.7 \mathrm{~m}$ long; mesh size $3.0-4.3 \mathrm{~cm})$. It has a stone weight each side and $32-40$ claws (each $25-32 \mathrm{~cm}$ long) for disrupting the sediment in front of the dredge mouth. Four dredges were simultaneously towed by a fishing boat for 15-20 min (towing speed ca. $100 \mathrm{~m} \mathrm{~min}^{-1}$ ). The Ishigeta dredge catches various kinds of fishes, crustaceans and molluscs, including small shrimps such as the southern rough shrimp, Trachysalambria curvirostris Stimpson, the body length (BL) of which

Table 1. Synopsis of samplings of Metapenaeus ensis in Osaka Bay.

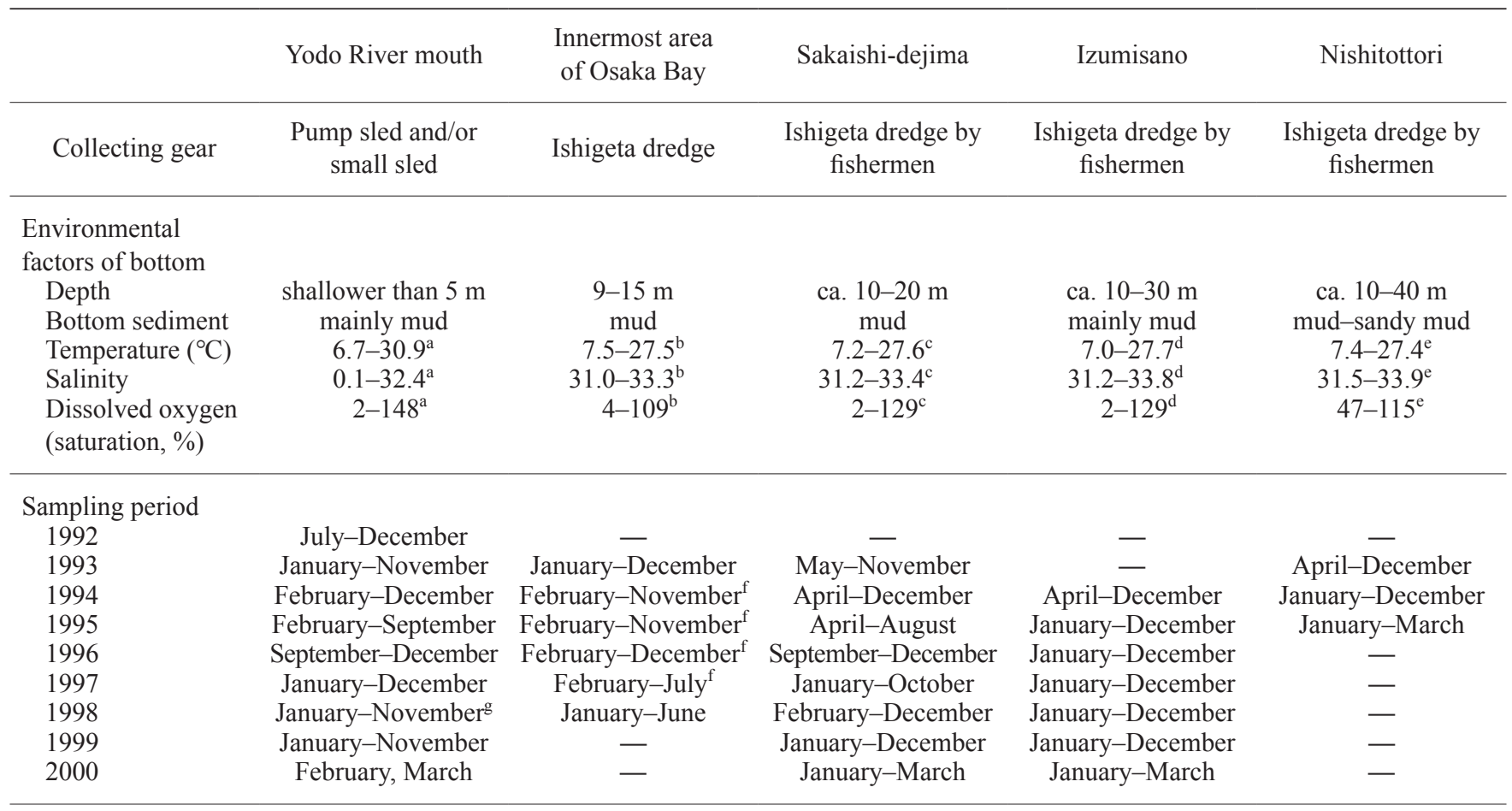

${ }^{\text {a }}$ Data measured in situ with STD meter and DO meter (Yamochi et al. 1995).

${ }^{b-e}$ Data from monthly observations by the Osaka Prefectural Fisheries Experimental Station from 1992 to 2000 (Nakajima et al. 2002).

${ }^{\mathrm{b}}$ Stns 17 \& 18;

${ }^{c}$ Stns 14 \& 15 ;

${ }^{\mathrm{d}}$ Stns $8-10,12,14,15 \& 20$;

${ }^{\mathrm{e}}$ Stns 2 \& 10.

${ }^{\mathrm{f}-\mathrm{g}}$ Includes samples caught by fishermen of the Osakashi Fishing Cooperative. ${ }^{\mathrm{f}}$ by small set nets; ${ }^{\mathrm{g}}$ by dip net. 


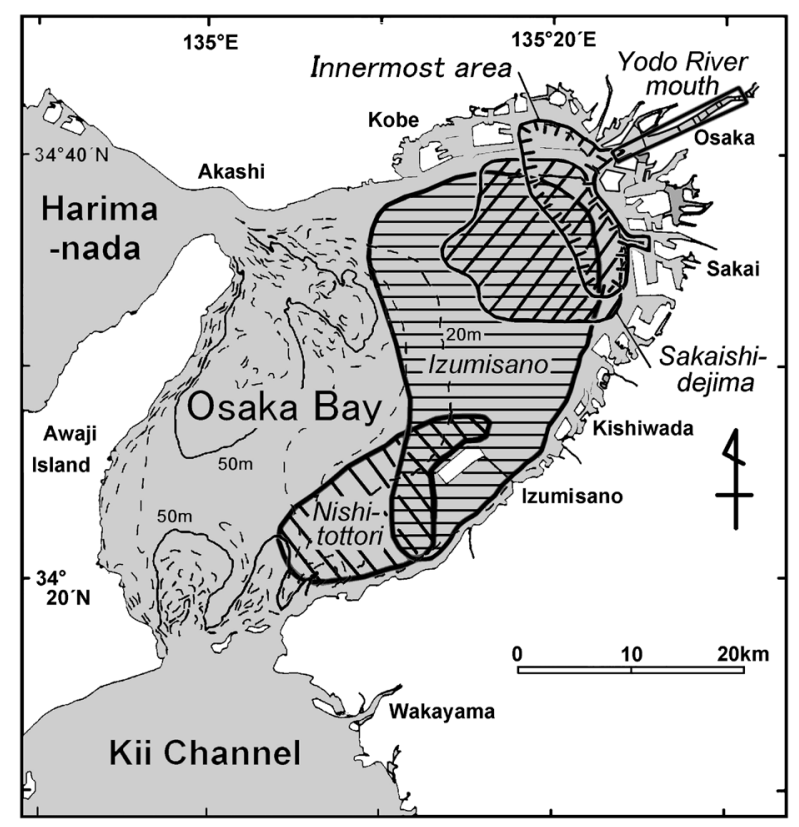

Fig. 1. Sampling areas of Metapenaeus ensis in Osaka Bay.

is ca. 40 to $90 \mathrm{~mm}$ (Kusakabe et al. 1989). Catches of $M$. ensis are also taken and these were purchased from fishermen belonging to three local fisheries cooperatives (Sakaishi-dejima, Izumisano and Nishitottori). The main collecting areas according to reports from the fishermen are shown in Fig. 1. Depth of these collecting areas is $10-40 \mathrm{~m}$ and the bottom material is mostly mud (Table 1). Metapenaeus ensis caught by fishermen of the Osakashi Fishing Cooperative were also examined. They were caught mainly by small set nets located outside the river mouth (in 1994-1997) or by dip net inside the river mouth (late August, 1998).

\section{Measurement and analysis}

All the sampled shrimps were measured (BL, from the base of the rostrum along the dorsal surface to the tip of the telson). Data for samples from the Yodo River mouth collected by pump sled and small sled were combined since the size compositions were similar. For convenience, shrimps collected inside the river mouth by fishermen of the Osakashi Fishing Cooperative were also included because of the similar habitat. Though many reared shrimps with tags were caught together with wild shrimps in the release experiment in the Yodo River mouth (Ariyama \& Sano 2000), data for the tagged shrimps were excluded in the present study. Sex was determined for shrimps caught in the innermost area (including the shrimps collected outside the river mouth by the fishermen) and the purchased shrimps from the Ishigeta dredge fishermen. For females, the presence of a stopper attached to the thelycum was also examined: those with a stopper are fully-reproducible (Ikematsu 1959, Abe et al. 1995).

Histograms for BL data were constructed at intervals of
$5 \mathrm{~mm}$. When apparently polymodal, cohorts were divided and the modes of each cohort calculated by the least squares method using MS-Excel Solver (Aizawa \& Takiguchi 1999). To estimate growth curves for female cohorts, series of the modes were chosen by conditions of transition of the modes and component ratios of the cohorts. The growth curves were calculated from the series of the modes also by the least squares method using MS-Excel Solver (Gorie 2001), provided that a seasonally fluctuating von Bertalanffy equation (as follows) fitted the growth curve (Akamine 2007):

$$
\begin{aligned}
& L_{t}=L_{\text {max }}\left[1-e^{-K\left\{F(t)-F\left(t_{0}\right)\right\}}\right] \\
& F(t)=t+\frac{A}{2 \pi} \sin 2 \pi\left(t-t_{1}\right)
\end{aligned}
$$

where $L_{t}$ is BL (mm) at age $t$ (month) from January 1 of the first year, $L_{\max }$ is maximum BL, $K$ is growth coefficient, $A$ is amplitude, and $t_{0}$ (month) and $t_{1}$ (month) are coefficients related to time (Gorie 2001, Akamine 2007). Because it is assumed that no negative growth of the shrimp occurs and negative growth appears in the case of $A>1$ (Akamine 2007), $A$ was fixed at 1. Calculations were not weighted for sample size. Each successive cohort is indicated by a suffix for the year concerned, expressed in 2-digit format: for example, 92-1 for the first cohort of 1992. In males, because cohorts could not be distinguished, growth curves were not analyzed.

Reproduction of the cohorts for each year was determined from the ratio of the stopper possession in the females from 1993 to 1998 . The yearly cohorts of females were separated at the intersecting point of the calculated normal distribution curves.

\section{Results}

\section{Body length composition}

A total of 96,898 M. ensis shrimps $(8,489$ from the Yodo River mouth, and 44,705 females and 43,704 males from the other areas) were examined. The smallest BL encountered was $6 \mathrm{~mm}$ (sex unknown), and the largest $175 \mathrm{~mm}$ in females and $144 \mathrm{~mm}$ in males. Seasonal changes in the BL composition for each area are shown in Figs. 2-6, and BL composition for all shrimps examined at each area is shown in Fig. 7. Representative seasonal changes of BL compositions for all the sampling areas (July 1993-June 1994, and July 1997-June 1998) are illustrated in Figs. 8 \& 9.

The Yodo River mouth contained mostly juveniles (less than $80 \mathrm{~mm} \mathrm{BL}$; Fig. 2). Small juveniles (less than $50 \mathrm{~mm}$ BL) occurred from August (1992 and 1998), September (1993, 1995-1997, 1999) or October (1994). No shrimps were collected in late July, 1992; late August, 1993; late June and early September, 1994; or late May, 1995. The ju- 


\section{Yodo River mouth}

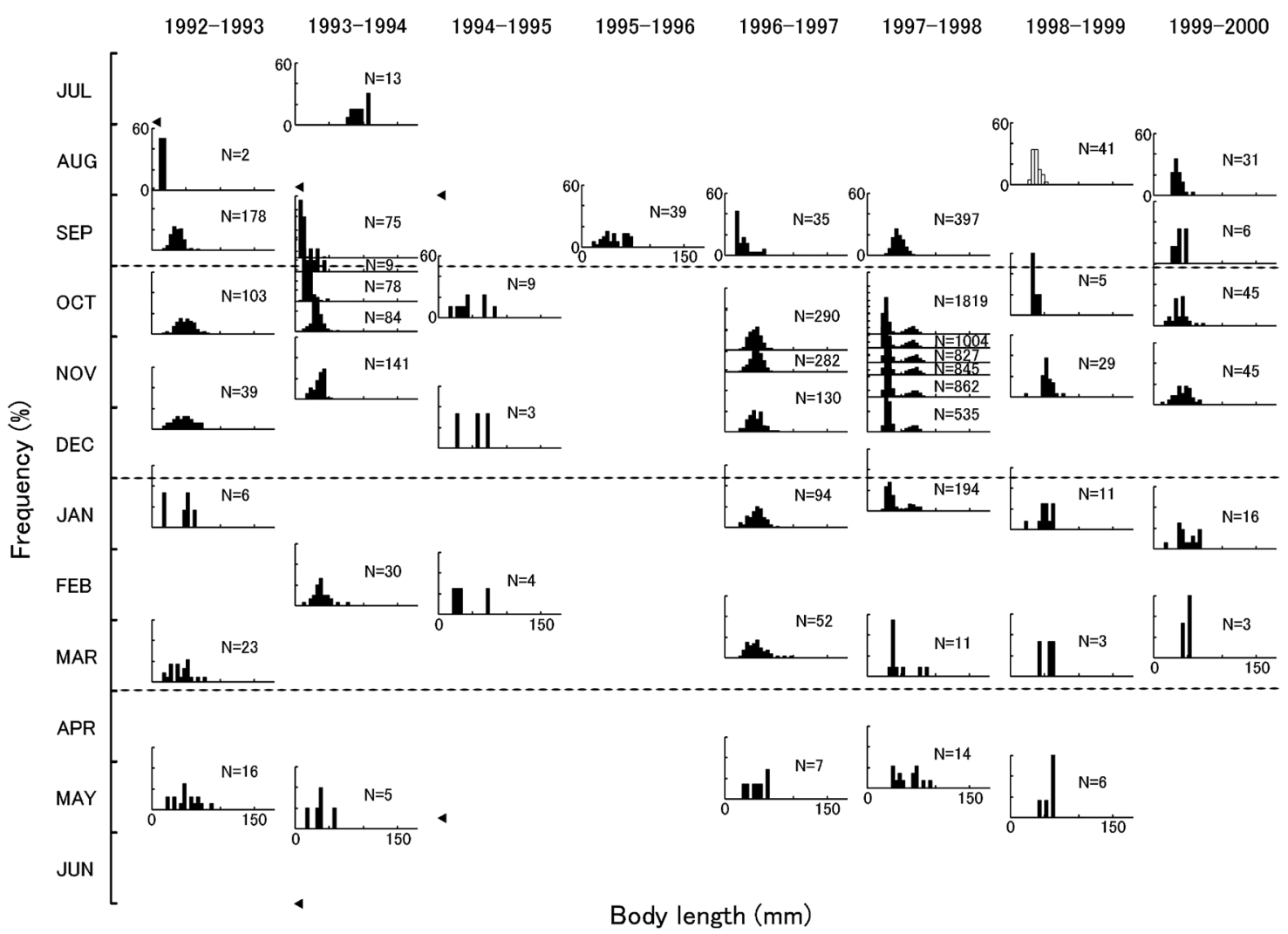

Fig. 2. Seasonal changes in the body length composition for the Metapenaeus ensis population in the Yodo River mouth (both sexes included). Open columns, shrimp caught by fishermen of the Osakashi Fishing Cooperative; triangles, no shrimp catch.

veniles consisted of one (1992, 1993, 1996, 1998 and 1999) or two (1994, 1995 and 1997) cohorts. They grew until about November and a part of the cohort usually continued to remain there until May. However, in 1993, large shrimps (78-110 mm BL) were collected in late July.

In the innermost area of Osaka Bay, relatively small shrimps (females ca. 85-120 mm BL, males ca. 80$110 \mathrm{~mm} \mathrm{BL}$ ) occurred almost throughout the year (Fig. 3), although no shrimps were collected in late August, 1994 and 1995. Small juveniles less than $50 \mathrm{~mm}$ BL were also collected in early December, 1993.

In the fishing ground of the Sakaishi-dejima Fishing Cooperative (the northeastern part of Osaka Bay), shrimps over a wide size range were caught (females ca. 75140 mm BL, males ca. 70-120 mm BL; Fig. 4). Relatively small shrimps $(<100 \mathrm{~mm}$ BL) were caught mainly in June-August in 1993, August-September in 1994, JuneAugust in 1995, May in 1997, September-October in 1998 and November 1999-March 2000.

In the fishing grounds of the Izumisano and Nishitottori Fishing Cooperatives (the mid-eastern and southeastern parts of Osaka Bay, respectively), mainly large shrimps (females ca. 105-160 mm BL, males ca. 95-130 mm BL) were caught (Figs. $5 \&$ 6). Shrimps caught in Nishitottori were larger than those in Izumisano (Fig. 7). Catches of relatively small shrimps (females $<120 \mathrm{~mm}$ BL, males $<110 \mathrm{~mm} \mathrm{BL}$ ) began in Izumisano in July and October in 1994; May, August and November in 1995; June and November in 1996; April, August and October in 1997; June and October in 1998; October in 1999; and March in 2000. In Nishitottori, catches of relatively small shrimps began from June-August in 1993, and June-August and October-November in 1994. These results suggest that recruitment to both fishing grounds occurs 1-3 times per year.

\section{Growth curve in females}

Estimated normal distribution curves of each separate cohort were well fitted to respective BL composition for both sexes (Figs. $8 \&$ 9). One to three cohorts occurred in each year and succession of the cohorts was assumed. Figure 10 shows the estimated growth curves of each cohort in females, and Table 2 shows the values of coefficients of the growth curves. Two or three cohorts per year were recognized from 1992 to 1998. Although the growth curves for cohorts $\underline{94-1}, \underline{96-1}$ and $\underline{96-2}$ are right-downwardly convex for the period of $<20 \mathrm{~mm} \mathrm{BL}$, the other growth curves showed good agreement with the seasonally fluctuating von Bertalanffy equation. Especially in major cohorts such 


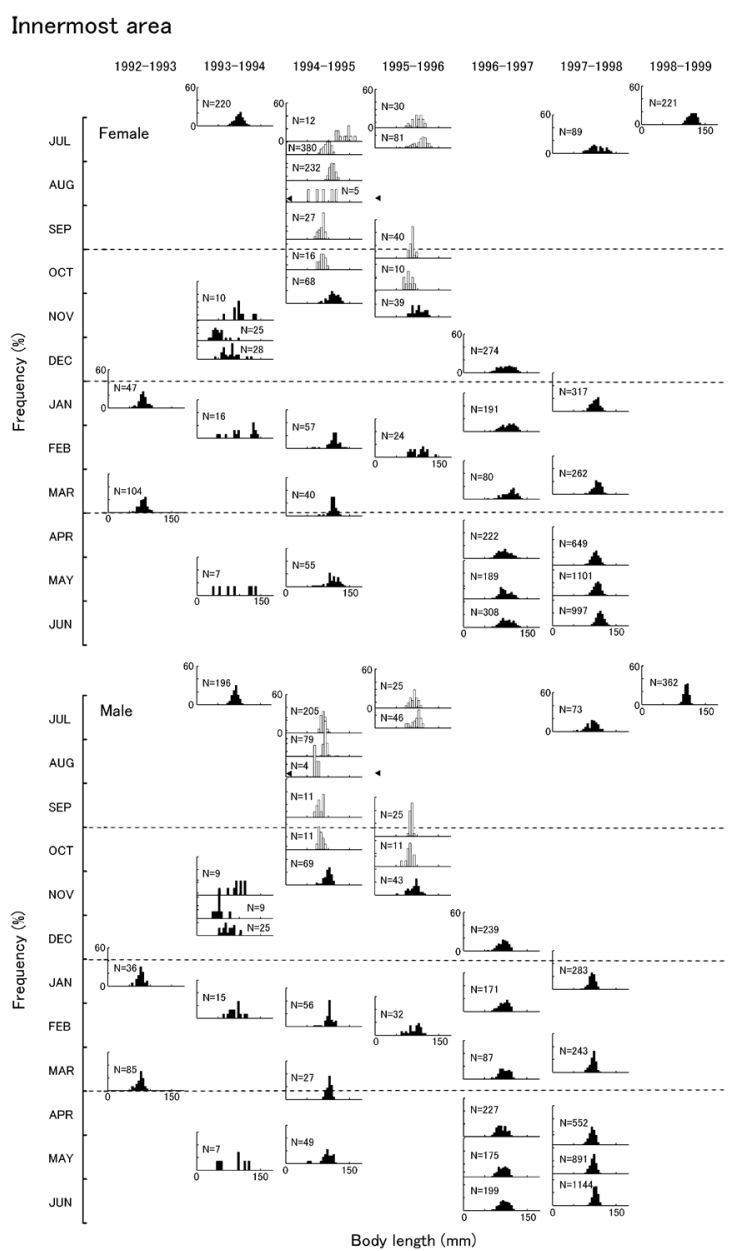

Fig. 3. Seasonal changes in body length composition for the Metapenaeus ensis population in the innermost area of Osaka Bay. Open columns, shrimp caught by fishermen of the Osakashi Fishing Cooperative; triangles, no catch by Ishigeta dredge.

as $92-1,93-2, \underline{96-3}, \underline{97-1}$ and $98-1$, the BL values for each area are almost smoothly continuous and the growth curves apparently fit well. On the contrary, in minor cohorts such as 93-1, 94-1, 95-1 and 96-1, it is unknown whether the growth curves fit or not because of insufficient data during the small-sized period.

Assuming that the growth curves (except for 94-1, 96-1 and 96-2) are exact, they indicate the following: larvae of the shrimp settle on the bottom from June to October; juveniles grow rapidly until about December, do not grow until about March, grow again until about December, do not grow again until about March, grow again and die in about July-September; a life span of about two years. Size in the first winter was variable with a range of ca. 35$125 \mathrm{~mm} \mathrm{BL}$, and early cohorts growing more rapidly than late cohorts. Size in the second winter was also variable with a range of ca. 105-150 $\mathrm{mm} \mathrm{BL}$, and growth in the second year was changeable in each cohort: for example, growth from ca. $40 \mathrm{~mm} \mathrm{BL}$ is rapid in $\underline{93-3}, \underline{94-3}$ and $\underline{97-2}$,

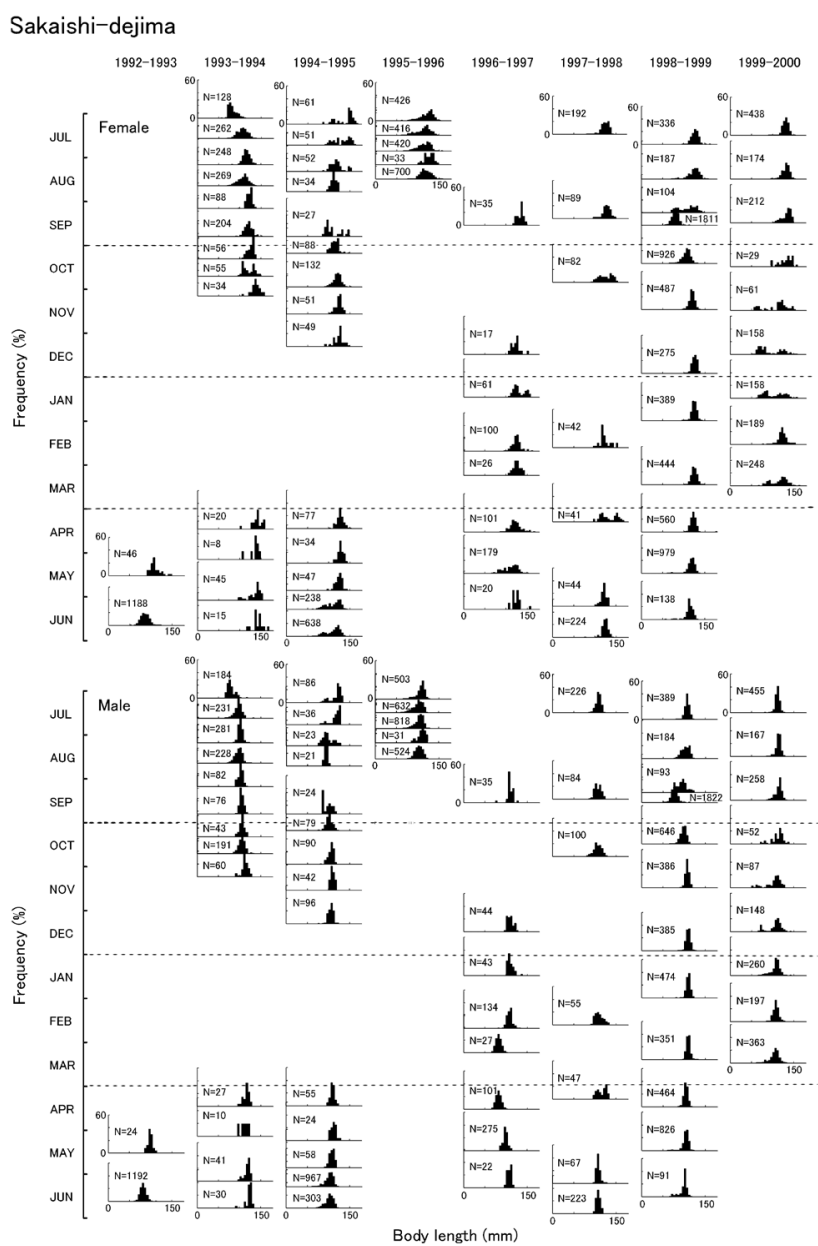

Fig. 4. Seasonal changes in the body length composition for the Metapenaeus ensis population collected by fishermen of the Sakaishi-dejima Fishing Cooperative.

but slow in $\underline{94-1}$ and $\underline{98-1}$.

\section{Reproduction}

The range of $\mathrm{BL}$ in the females possessing a stopper was $76-168 \mathrm{~mm}$. Figure 11 shows the ratio of stopper possession in the second year (ca. 0.5-1.5 years old) and third year (ca. 1.5-2.5 years old) from 1993 to 1998. In the second year, the females possessing a stopper occurred mainly from June or July to September, with a peak in July-August; and in the third year, stopper occurrence was from June to August or September (with a peak in July) in 1993, 1994, 1996 and 1998, but no stopper-possessing females were observed in 1995 and 1997.

\section{Discussion}

The present study confirmed the previous finding that the Yodo River mouth serves as a nursery for M. ensis (Yamochi et al. 1995). Because some cohorts were not observed in the river mouth (i.e. 93-1, 94-1 in Fig. 10), the nursery is considered to be extended to other brackish 


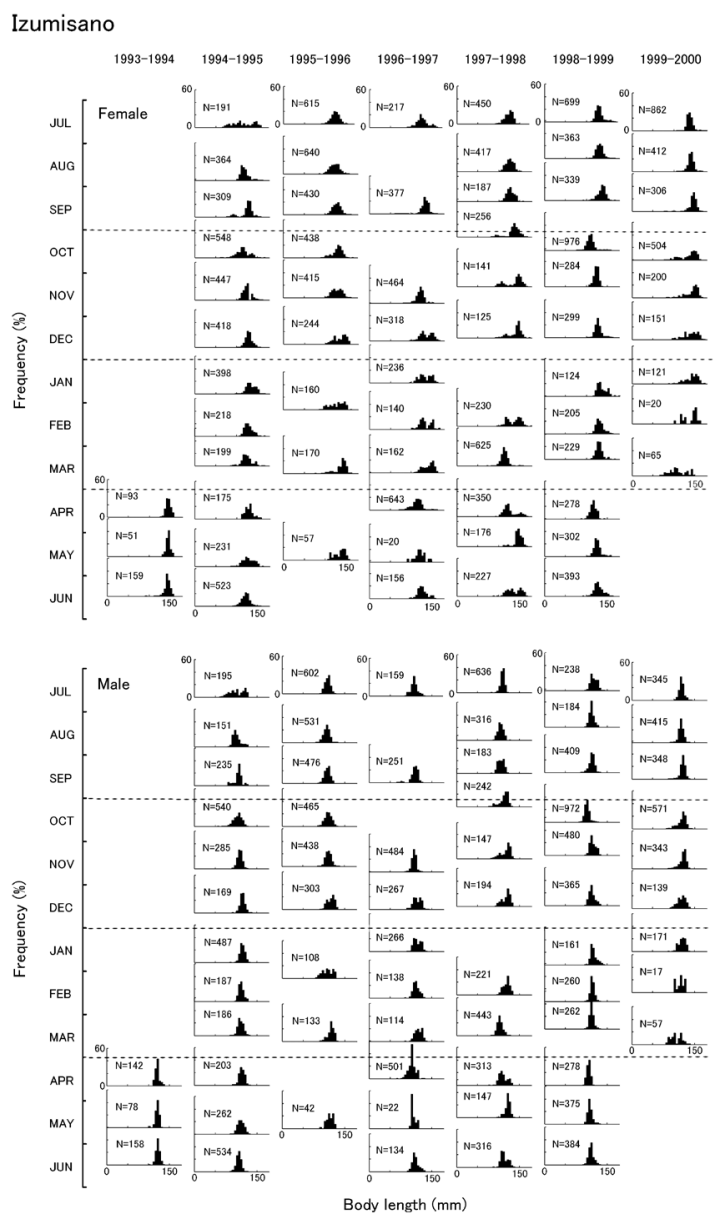

Fig. 5. Seasonal changes in the body length composition for the Metapenaeus ensis population collected by fishermen of the Izumisano Fishing Cooperative.

areas in Osaka Bay: many other papers have reported that nurseries are formed in brackish areas such as estuaries (e.g. Ota 1949, Ishida et al. 1985, Staples et al. 1985, Viet \& Sakuramoto 2013). The importance of mangroves as nursery areas for $M$. ensis has also been pointed out (Robertson \& Duke 1987, Primavera 1998). However, on the bottom of the Yodo River mouth, there was no vegetation and only a small amount of dead leaves and stalks of the common reed Phragmites australis (Cav.) Trin. accumulated, suggesting that vegetation in the nursery is not always necessary to sustain the juveniles.

The settlement period of juveniles in Osaka Bay is estimated to occur from June to October, whereas it is all year round in warmer countries (Su \& Liao 1994, Leung 1997, Primavera 1998, Viet \& Sakuramoto 2013). Although small juveniles were not collected in June and July in the estuaries of both the Yodo River (Fig. 2) and the Imagawa River, Fukuoka Prefecture (Ishida et al. 1985, Tokuda et al. 1991), juveniles collected in the Imagawa River on August 18, 1988 (Tokuda et al. 1990) were divided into two cohorts and the larger one (ca. $40-70 \mathrm{~mm} \mathrm{BL}$ ) is estimated to have settled in July. Because the reproductive period in

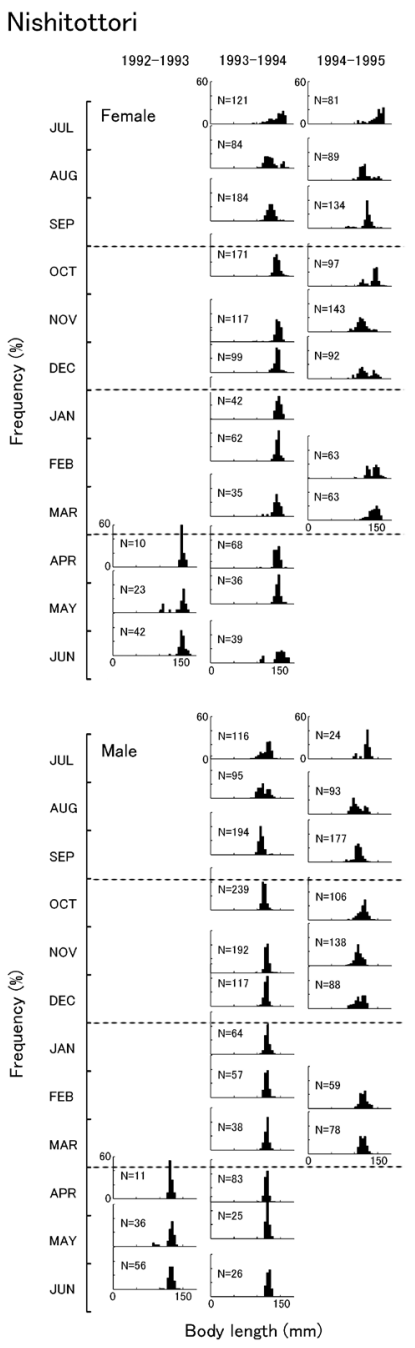

Fig. 6. Seasonal changes in the body length composition for the Metapenaeus ensis population collected by fishermen of the Nishitottori Fishing Cooperative.

Osaka Bay is similar to the Buzen Sea, a part of Suo-nada (Tokuda et al. 1997), it is possible that the juveniles settle from July also in Osaka Bay.

In Osaka Bay, medium-sized specimens (ca. 80-120 mm BL) occurred almost throughout the year in the innermost area (depth 9-15 m; Fig. 3). Similarly, small-sized shrimps $(<100 \mathrm{~mm} \mathrm{BL})$ were mainly distributed $1.5 \mathrm{~km}$ offshore (depth: 5-6 m) in the Buzen Sea (Katayama et al. 2001). It is therefore deduced that juveniles migrate from the nursery to shallow sea areas adjacent to the nursery after growth to ca. $80 \mathrm{~mm} \mathrm{BL}$. In the innermost area, because there were no shrimps in August owing to severe hypoxia (Ariyama et al. 1997) and many shrimps were collected from November (Fig. 3), the season when shrimp migrate from the river mouth is estimated to be mainly in the autumn: in the Buzen Sea, migration occurs in October (Katayama et al. 2001). On the other hand, in warmer regions, the period of migration is longer ( $\mathrm{Su} \&$ Liao 1994, Viet \& 


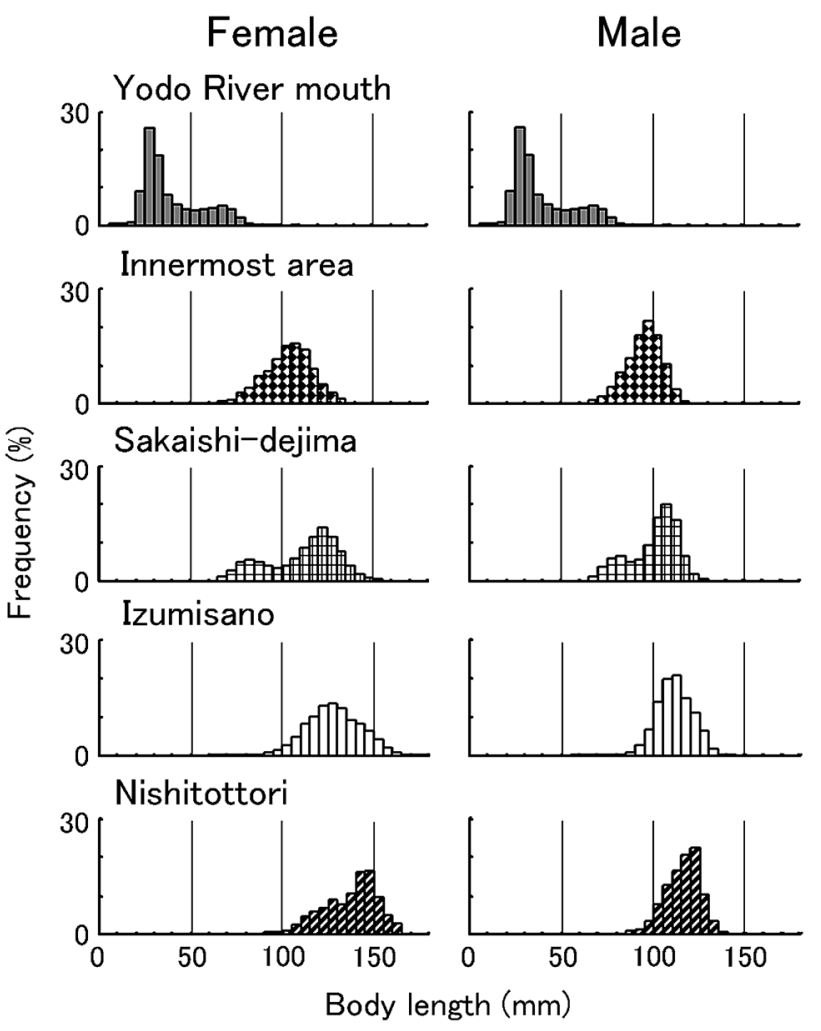

Fig. 7. Body length composition for all Metapenaeus ensis populations at each area. Compositions for both sexes in the Yodo River mouth are the same for lack of discrimination.

Sakuramoto 2013).

Comparing the $\mathrm{BL}$ compositions for each area, M. ensis inhabiting the innermost area are estimated to recruit into the nearby fishing ground of Sakaishi-dejima (Figs. $3 \& 4$ ), but the recruitment period and number of recruits varied each year. Migration after recruitment is probably southward (towards deeper areas, from ca. $10-20 \mathrm{~m}$ to ca. $10-40 \mathrm{~m}$ ), because BL tends to increase with depth (Fig. 7). This migration in Osaka Bay resembles that in the Buzen Sea (Katayama et al. 2001). Although migration towards deeper water is general for the shrimp (e.g. Cheung 1964, Su 1988, Sakaji \& Komatsu 2004), two-way migration (offshore and onshore) has also been observed (Ota 1949, Kochi District Fisheries Improvement Council \& Kochi Prefectural Kochi Fisheries Guidance Office 1971, Crocos et al. 2001).

Comparison of the largest sizes and life span with previous research is shown in Table 3. The maximum CL (carapace length) was larger in Kii Channel (Ueta et al. 1993) and Suo-nada (Yatuyanagi \& Maekawa 1956) and smaller in Lake Naka-umi (Ota 1949) and Bisan-seto (Yasuda 1956). However, there is little difference among the other localities including Osaka Bay. Although life span varies from 1 to 2.5 years in these studies, there is a possibility of inaccuracy because the estimated growth may be incorrect (see Introduction).

Growth of the M. ensis cohorts (except for 94-1, 96-1 and $\underline{96-2}$ ) showed good agreement with the seasonally fluctuating von Bertalanffy equation (Fig. 10). The reason for

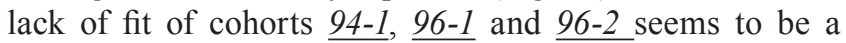
shortage of data for small-sized shrimps. The settlement time of 93-1 and 95-1 (and probably in 94-1 and 96-1) was estimated to be in June, if the estimated growth curves are accurate. Since the reproductive periods began from June, and it takes ca. 40 days to rear from hatching to reach a juvenile of $12 \mathrm{~mm}$ total length (Hayashi 1991), it is possible to confuse these cohorts with those that settled in the previous year. However, because all of 92-2, 93-3, 94-2 and 95-2 are major cohorts and their estimated growth curves are probably correct, confusion with juveniles hatching in the previous year seems unlikely and the settlement of the cohorts seems to have been in July. Study of growth using an age-determination method such as lipofuscin (Sheehy et al. 1995) is required to investigate this further. In males, succession of the modes with time and disappearance of large-sized individuals are similar to those of females (Figs. 2-6, $8 \&$ 9); therefore, males probably grow and die over a similar period to females, in spite of their smaller body size.

The size range of reproducible females is wide (76$168 \mathrm{~mm} \mathrm{BL}$ ) in the present study, suggesting that the growth of the shrimp is indeterminate (Hartnoll 1985). The reproductive season was mainly from June to September (peak: July-August) and the bottom temperature when reproducible females occurred at a high frequency ranged from 19 to $25^{\circ} \mathrm{C}$ (Nakajima et al. 2002). This season is similar to that of many other habitats in Japan, except for Tosa Bay (from middle May to early October; Kochi District Fisheries Improvement Council \& Kochi Prefectural Kochi Fisheries Guidance Office 1971). Spawning season varies in other countries (Cheung 1964, Su 1988, Courtney et al. 1989, Chu et al. 1993). In Fig. 11, reproducible females were observed mainly in July-August of the second year (ca. 0.5-1.5 years old) and in July of the third year (ca. 1.52.5 years old). This suggests that the female $M$. ensis is able to copulate twice in its life span and that spawning in the second year is later than in the third year. However, in 1995 and 1997, reproducible females were not observed in the third year. Investigation of $M$. ensis caught in the southern area including the fishing ground of the Nishitottori Fishing Cooperative was not conducted in these years, so it is possible that $M$. ensis caught in Izumisano may migrate to the southern area and reproduce there.

The present study clarified female growth and reproduction and the ontogenetic migration of $M$. ensis from settlement to death in Osaka Bay. Abe et al. (1995) studied M. ensis in the same locality. They estimated that: (1) two seasonal cohorts of the shrimp are present; (2) in the early cohort, life span is about two years and spawning occurs twice; and (3) in the late cohort, life span is about two and half years and spawning occurs only once. Compared with the present study, the growth and reproduction of the early cohort are almost identical. Conversely, in the late cohort, 

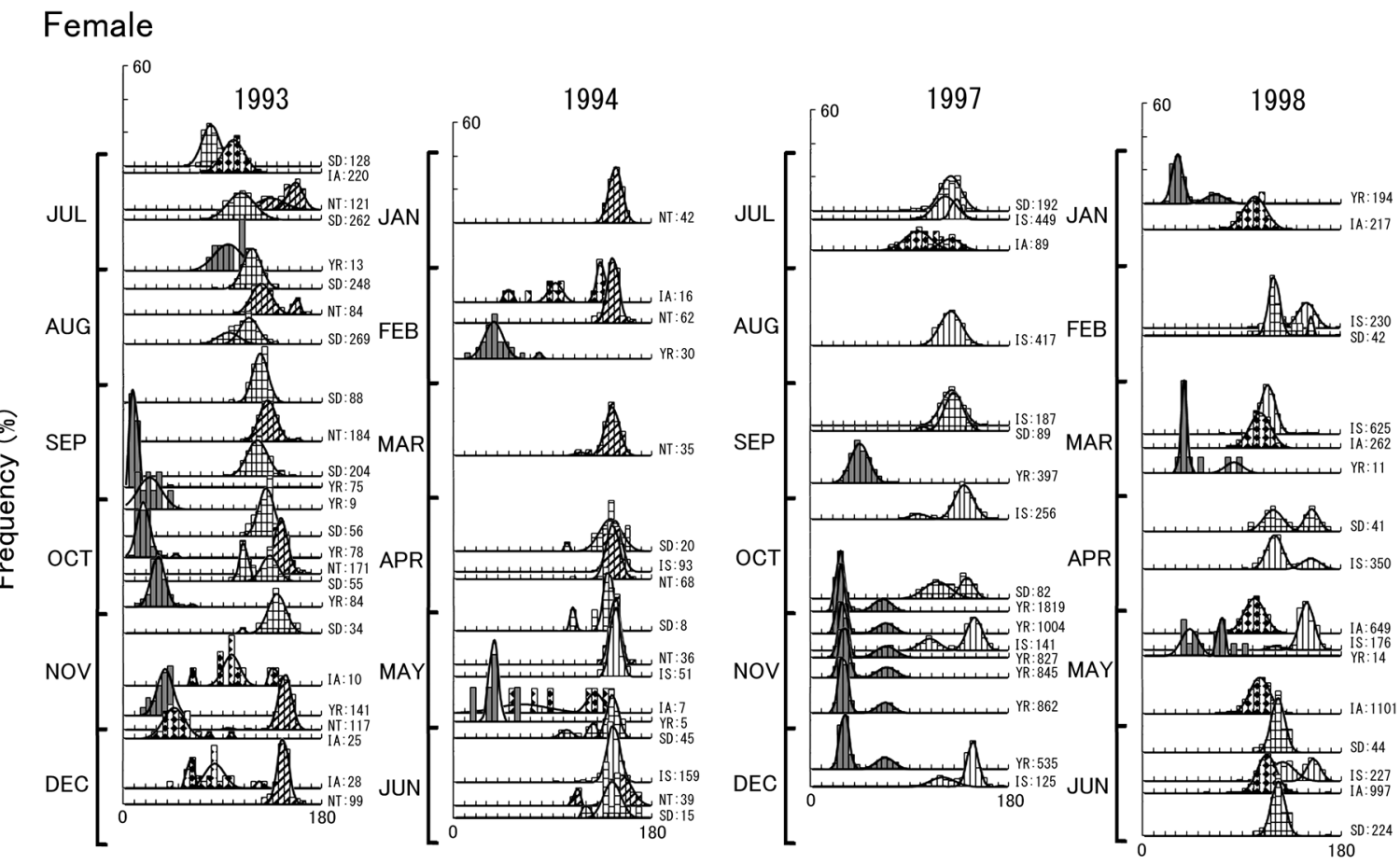

Body length (mm)

IIR $\boxplus I A \boxplus S D \boxplus I S \boxplus N T$

Fig. 8. Representative seasonal changes in the body length composition for female Metapenaeus ensis in all sampling areas from July, 1993 to June, 1994, and from July, 1997 to June, 1998. Calculated normal distribution curves for each separate cohort are also shown. Characters on the right of the abscissae indicate the sampling area and the numbers examined. YR, Yodo River mouth; IA, innermost area; SD, Sakaishi-dejima; IS, Izumisano; NT, Nishitottori.
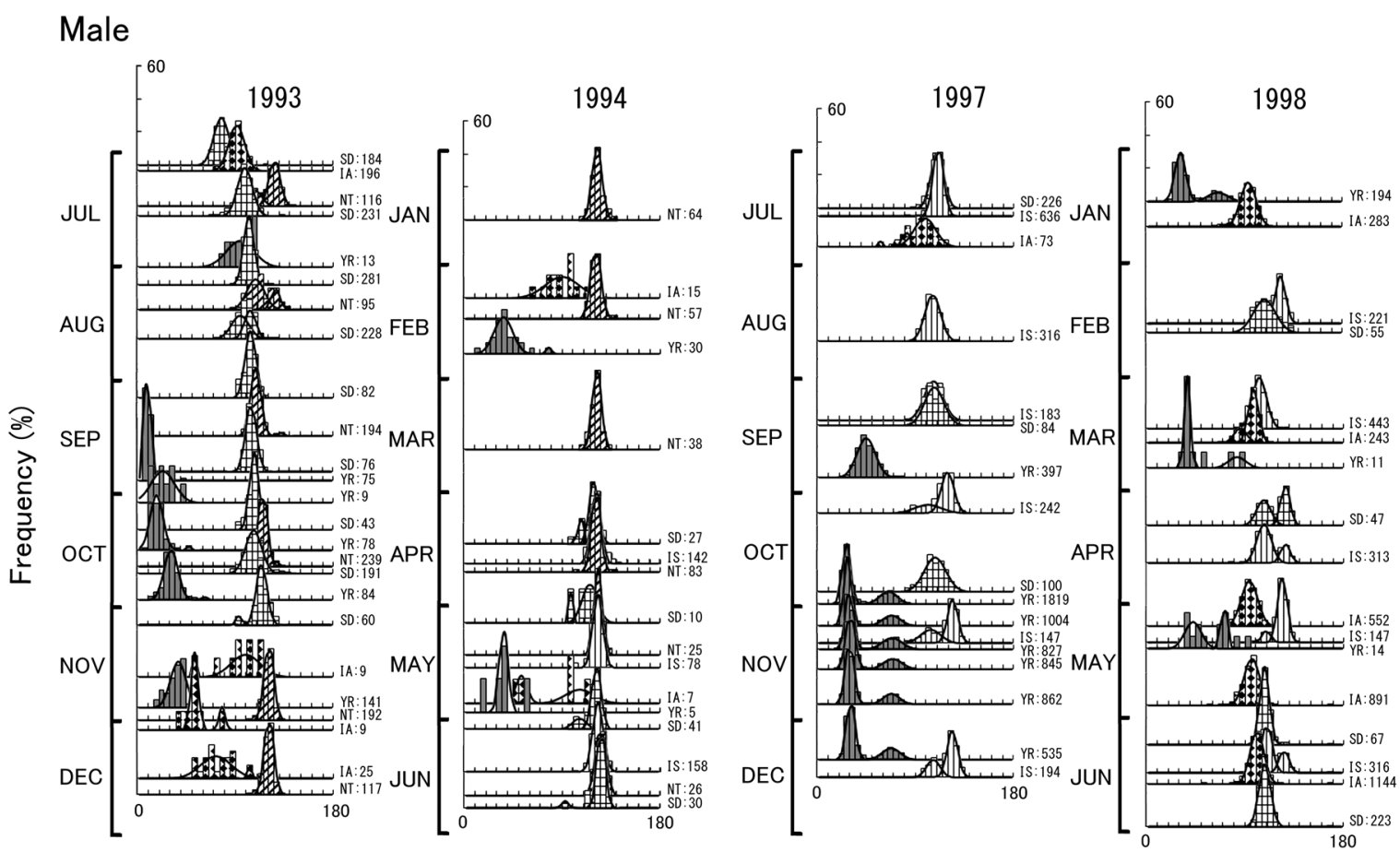

Body length $(\mathrm{mm})$

II YR $\boxplus I A \boxplus S D \boxplus I S \boxplus N T$

Fig. 9. Representative seasonal changes in the body length compositions for male Metapenaeus ensis in all sampling areas from July, 1993 to June, 1994, and from July, 1997 to June, 1998. See Fig. 8 for further details. 


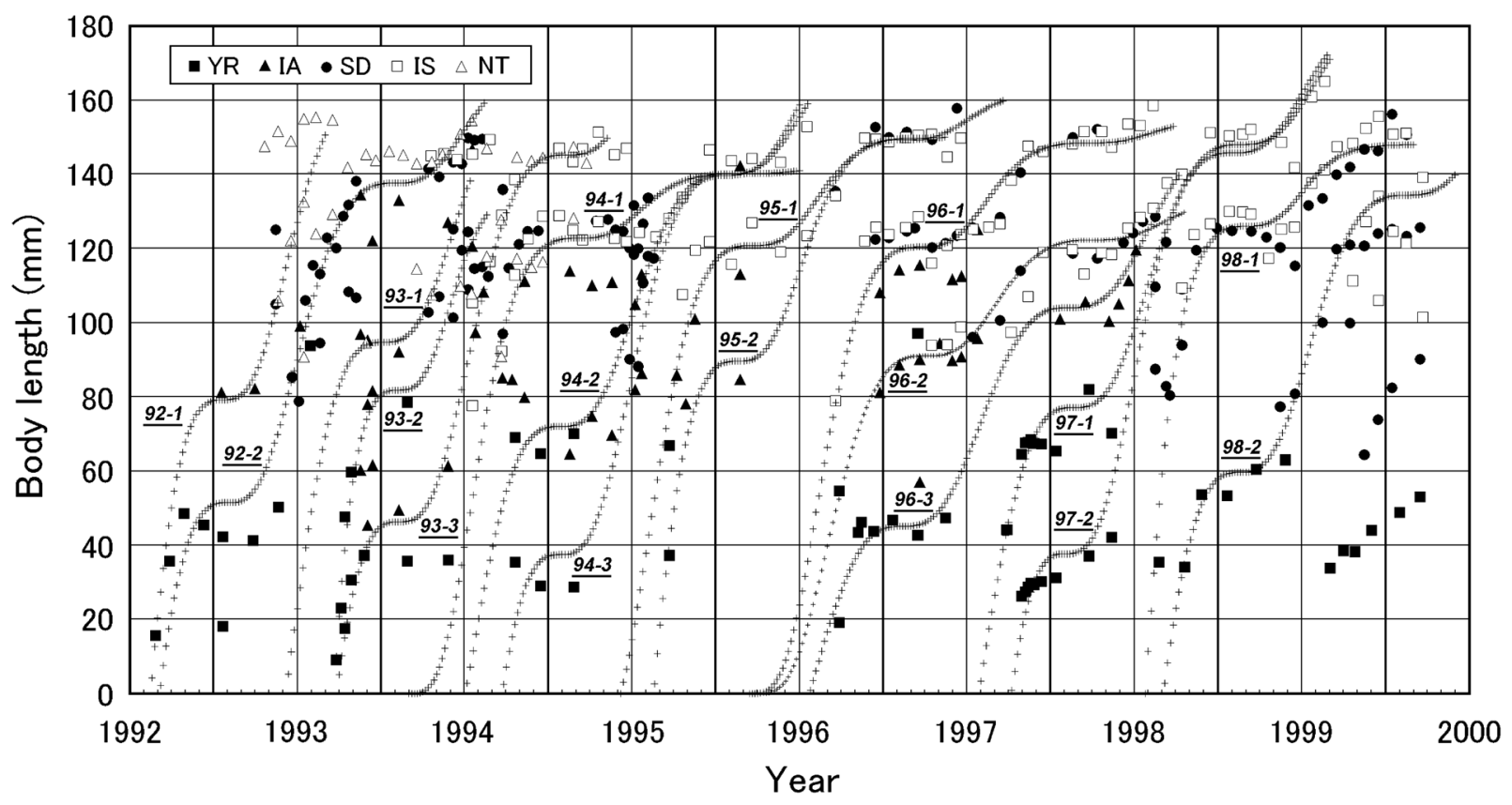

Fig. 10. Calculated modes and growth curves for each cohort in female Metapenaeus ensis. Underlined characters are cohort names.

Table 2. Values of coefficients in the growth curves ${ }^{\mathrm{a}}$ of each cohort.

\begin{tabular}{cclcc}
\hline Cohort & $\begin{array}{c}L_{\max } \\
(\mathrm{mm})\end{array}$ & $K$ & $\begin{array}{c}t_{0} \\
\text { (month) }\end{array}$ & $\begin{array}{c}t_{1} \\
\text { (month) }\end{array}$ \\
\hline $92-1$ & 189 & 1.48 & 7.50 & -5.31 \\
$92-2$ & 189 & 0.988 & 8.12 & -4.97 \\
$93-1$ & 204 & 0.948 & 5.23 & -5.81 \\
$93-2$ & 139 & 3.18 & 8.64 & -4.74 \\
$93-3$ & 205 & 0.980 & 8.82 & -4.69 \\
$94-1$ & 143 & 1.96 & 2.26 & -3.74 \\
$94-2$ & 213 & 0.656 & 6.08 & -5.15 \\
$94-3$ & 208 & 0.918 & 8.70 & -5.14 \\
$95-1$ & 158 & 1.53 & 5.20 & -3.28 \\
$95-2$ & 166 & 1.53 & 7.54 & -4.42 \\
$96-1$ & 157 & 1.46 & 2.77 & -3.25 \\
$96-2$ & 139 & 1.07 & 3.14 & -2.86 \\
$96-3$ & 278 & 0.292 & 6.73 & -4.63 \\
$97-1$ & 222 & 0.672 & 6.86 & -4.32 \\
$97-2$ & 199 & 1.11 & 9.17 & -4.88 \\
$98-1$ & 150 & 2.62 & 6.80 & -3.93 \\
$98-2$ & 178 & 0.992 & 8.10 & -4.44 \\
\hline
\end{tabular}

a Equations of the growth curves are as follows: $L_{t}=L_{\max }[1-$ $\left.e^{-K\left\{F(t)-F\left(t_{0}\right)\right\}}\right], F(t)=t+\frac{1}{2 \pi} \sin 2 \pi\left(t-t_{1}\right)$, where $L_{t}$ is BL $(\mathrm{mm})$ at age $t$ (month) from January 1 of the first year, $L_{\max }$ is maximum $\mathrm{BL}(\mathrm{mm}), K$ is growth coefficient, and $t_{0}$ (month) and $t_{1}$ (month) are coefficients related to time.

growth and reproduction are relatively similar to those of 96-2 and 96-3; however, Abe et al. (1995) may have misidentified the quickly-grown cohorts in the first year (i.e. 94-1, 95-1, 96-1 and $\underline{98-1}$ ) as the late cohort.

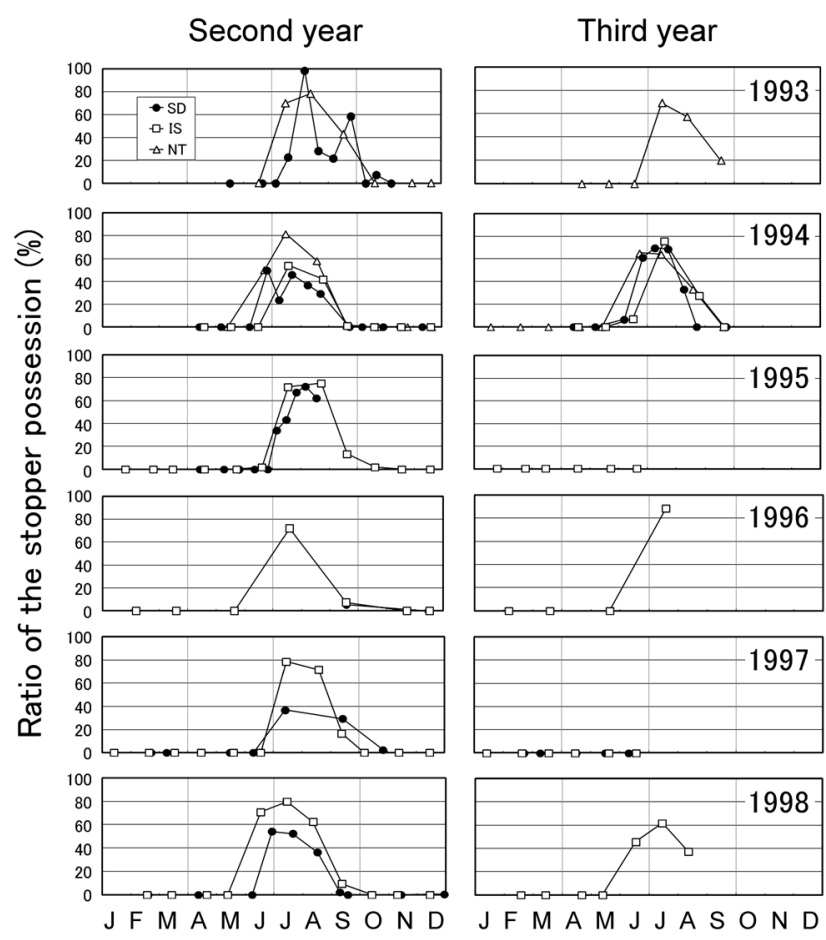

Fig. 11. Ratio of stopper possession of female Metapenaeus ensis in their second year (age: about $0.5-1.5$ years old) and third year (age: about 1.5-2.5 years old) from 1993 to 1998.

The present study revealed large differences from year to year in the number of cohorts and their growth. The differences are probably caused by various environmental factors. Hypoxia is assumed to be one such factor. Dis- 
Table 3. Maximum sizes and life span of Metapenaeus ensis in various localities.

\begin{tabular}{|c|c|c|c|c|c|}
\hline Locality & $\begin{array}{l}\text { Latitude, Longitude } \\
\text { (center of } \\
\text { studying area) }\end{array}$ & $\begin{array}{l}\text { Maximum size } \\
\text { in females } \\
(\mathrm{CL}, \mathrm{mm})\end{array}$ & $\begin{array}{l}\text { Maximum } \\
\text { size } \\
\text { in males } \\
(\mathrm{CL}, \mathrm{mm})\end{array}$ & Life span & References \\
\hline Osaka Bay & $34^{\circ} 29^{\prime} \mathrm{N}, 135^{\circ} 10^{\prime} \mathrm{E}$ & $52.7^{\mathrm{a}}$ & $39.1^{\mathrm{a}}$ & about 2 years & Present study \\
\hline Lake Naka-umi & $35^{\circ} 28^{\prime} \mathrm{N}, 133^{\circ} 12^{\prime} \mathrm{E}$ & 43 & 31 & 1 year & Ota $(1949)$ \\
\hline Kii Channel & $34^{\circ} 01^{\prime} \mathrm{N}, 134^{\circ} 47^{\prime} \mathrm{E}$ & 45 & 38 & $12-15$ (rarely 24 ) months & Yasuda (1956) \\
\hline Kii Channel & $34^{\circ} 01^{\prime} \mathrm{N}, 134^{\circ} 47^{\prime} \mathrm{E}$ & $56.2-58.0^{\mathrm{a}}$ & $49.0-50.6^{\mathrm{a}}$ & 1 (rarely 2 ) years & Ueta et al. (1993) \\
\hline Osaka Bay & $34^{\circ} 29^{\prime} \mathrm{N}, 135^{\circ} 10^{\prime} \mathrm{E}$ & $52.7-54.5^{\mathrm{a}}$ & $41.0-42.6^{\mathrm{a}}$ & 2 or 2.5 years & Abe et al. (1995) \\
\hline Bisan-seto & $34^{\circ} 28^{\prime} \mathrm{N}, 133^{\circ} 27^{\prime} \mathrm{E}$ & 33 & 26 & $12-15$ (rarely 24) months & Yasuda (1956) \\
\hline Suo-nada & $33^{\circ} 57^{\prime} \mathrm{N}, 131^{\circ} 25^{\prime} \mathrm{E}$ & 55 & 46 & 1 (rarely 2) years & Yatuyanagi \& Maekawa (1956) \\
\hline Tosa Bay & $33^{\circ} 27^{\prime} \mathrm{N}, 133^{\circ} 35^{\prime} \mathrm{E}$ & $53.8^{\mathrm{a}}$ & $37.2^{\mathrm{a}}$ & 1 year and several months & $\begin{array}{l}\text { Kochi District Fisheries Improve- } \\
\text { ment Council \& Kochi Prefectural } \\
\text { Kochi Fisheries Guidance Office } \\
\text { (1971) }\end{array}$ \\
\hline Tosa Bay & $33^{\circ} 27^{\prime} \mathrm{N}, 133^{\circ} 35^{\prime} \mathrm{E}$ & 44 & 36 & about 2 years in max. & Sakaji \& Komatsu (2004) \\
\hline Ariake Sea & $32^{\circ} 53^{\prime} \mathrm{N}, 130^{\circ} 23^{\prime} \mathrm{E}$ & 47.6 & 34.5 & 1 (rarely 2) years & Ikematsu (1959) \\
\hline Hong Kong & $22^{\circ} 23^{\prime} \mathrm{N}, 114^{\circ} 07^{\prime} \mathrm{E}$ & 49 & 36 & $15-20$ months & Cheung (1964) \\
\hline
\end{tabular}

${ }^{a}$ Converted from body length using Abe et al. (1995)'s equations: $B L=2.843 C L+25.09$ [females] and $B L=3.127 C L+21.76$ [males].

solved oxygen concentration in the bottom layer fluctuates widely over short periods (Diaz et al. 1992) and therefore M. ensis populations presumably move elsewhere to avoid hypoxia, which would explain why no $M$. ensis were collected in the (hypoxic) innermost area in August, 1994 and 1995 (Fig. 3), and mass catches by fishermen attributed to the avoidance of hypoxia were observed in Osaka Bay (Abe et al. 1995). However, extremely severe hypoxia presumably affects survival, and thus the number of cohorts. Detailed research is required on the relationship between survival-growth of $M$. ensis and hypoxia and other environmental factors, such as temperature (Abe et al. 1995, Park \& Loneragan 1999), diet, predation (Primavera 1997) and disease (Momoyama et al. 1997).

\section{Acknowledgements}

We express our sincere thanks to fishermen of the Osakashi Fisheries Cooperative and S. Kyogara of the Sakaishi-dejima Fisheries Cooperative for help with sampling. We also thank Dr. S. Yamochi (present affiliation: Osaka City University), Y. Nabeshima, H. Ozato and K. Nishikawa of our center and students of Kinki University (M. Nakazato, M. Suga, Y. Nakai, J. Takahashi, T. Yamamoto, M. Ishado and N. Kitawaki) for help with field surveys and measurements. We are also grateful to Dr. Y. Henmi of Kumamoto University, Dr. T. Kusakabe of our center and two anonymous reviewers for their critical comments on the manuscript, and to Dr. I. G. Gleadall of Tohoku University for English proofreading.

\section{References}

Abe T, Kusakabe T, Nabeshima Y, Tsujino K (1995) Oosakawan niokeru yoshiebi no gyogyouseibutsugakuteki-kenkyuu [Fisheries biology of the greasyback shrimp Metapenaeus ensis in Osaka Bay]. Bull Osaka Pref Fish Exp Stn 9: 57-75. (in Japanese)

Aichi Prefectural Fisheries Experimental Station (1942) Shouwa16-nendo aichikensan-juuyou-ebirui-seitai-chousa [Investigation on the important shrimps in Aichi Prefecture in 1941]. Aichi Prefectural Fisheries Experimental Station, Gamagori, 38 pp. (in Japanese)

Aizawa Y, Takiguchi N (1999) MS-Excel wo mochiita saizudosuubunpu kara nenrei-sosei wo suitei suru houhou no kentou [Consideration of the methods for estimating the age-composition from the length frequency data with MS-Excel]. Bull Jpn Soc Fish Oceanogr 63: 205-214. (in Japanese)

Akamine T (2007) Suisan-shigenkaiseki no kiso [Fundamentals of Fishery Resource Analysis]. Koseisha-Koseikaku, Tokyo, 115 pp. (in Japanese)

Ariyama H (2004) Yodogawa-kakouiki no yakuwari -oogatateiseidoubutsu wo chuushin toshite- [Ecological significance of the estuary of the Yodo River with special reference to the habitat of megabenthos]. Bull Kansai Organization Nat Conserv 26: 113-122. (in Japanese)

Ariyama H, Sano M (2000) Yodogawa-kakouiki ni houryuu shita kinsenhyoushiki-yoshiebi no saiho oyobi kyakusonshou-joukyou nitsuite [Capture and leg injuries of the greasyback shrimp Metapenaeus ensis with gold bit tag released at the mouth of the Yodo River in Osaka Prefecture]. Saibai Giken 28: 25-37. (in Japanese)

Ariyama H, Yamochi S, Sano M (1997) Dynamics of megabenthos in the innermost area of Osaka Bay, II. Seasonal changes in number of individuals, distribution and body length composition of dominant species. Bull Coast Oceanogr 35: 83-91. (in 
Japanese with English abstract)

Cheung TS (1964) Contributions to the knowledge of the life history of Metapenaeus ensis and other economic species of penaeid prawns in Hong Kong. J Appl Ecol 1: 369-386.

Chu KH, Tam YK, Chung CK, Ng WL (1993) Morphometric relationships and reproductive maturation of the shrimp, Metapenaeus ensis, from commercial catches in Hong Kong. Fish Res 18: 187-197.

Courtney AJ, Dredge MCL, Masel JM (1989) Reproductive biology and spawning periodicity of endeavour shrimps Metapenaeus endeavouri (Schmitt, 1926) and Metapenaeus ensis (de Haan, 1850) from a central Queensland (Australia) fishery. Asian Fish Sci 3: 133-147.

Crocos PJ, Park YC, Die DJ, Warburton K, Manson F (2001) Reproductive dynamics of endeavour prawns, Metapenaeus endeavouri and M. ensis, in Albatross Bay, Gulf of Carpentaria, Australia. Mar Biol 138: 63-75.

Diaz RJ, Neubauer RJ, Schaffner LC, Pihl L, Baden SP (1992) Continuous monitoring of dissolved oxygen in an estuary experiencing periodic hypoxia and the effect of hypoxia on macrobenthos and fish. In: Marine Coastal Eutrophication (eds Vollenweider RA, Marchetti R, Viviani R). Elsevier, Amsterdam, pp. 1055-1068.

Gorie S (2001) Estimation of the parameters in von Bertalanffy's growth formula by MS-Excel. Suisanzoshoku 49: 519-527. (in Japanese with English abstract)

Hartnoll RG (1985) Growth, sexual maturity and reproductive output. In: Factors in Adult Growth (Crustacean Issues 3) (ed Wenner AM). A.A.Balkema, Rotterdam, pp. 101-128.

Hayashi K (1992) Nihonsan-ebirui no bunrui to seitai. I. konsaiamoku (kurumaebi-jouka, sakuraebi-jouka) [Dendrobranchiata Crustaceans from Japanese Waters]. Seibutsu-Kenkyusha, Tokyo, 300 pp. (in Japanese)

Hayashi Y (1991) Yoshiebi no shubyouseisan [Seedling production of the greasyback shrimp]. In: Manual of Seedling Production. Osaka Prefectural Fisheries Experimental Station, Osaka, pp. 1-23. (in Japanese)

Holthuis LB (1980) Shrimps and Prawns of the World. An Annotated Catalogue of Species of Interest to Fisheries. FAO, Rome, $271 \mathrm{pp}$.

Ikematsu W (1959) On the life-history of Metapenaeus monoceros (FABRICIUS) in Ariake Sea. Rep Invest Ariake Sea 5: 19-29. (in Japanese with English abstract)

Ishida M, Arie Y, Nakamura K, Oda K, Ushima H, Shibata T (1985) Yoshiebi-houryuu-gijutsu nitsuite-III [On the development in releasing technique of the greasyback shrimp-III]. Rep Invest Fukuoka Pref Buzen Fish Exp Stat 1983: 153-173. (in Japanese)

Katayama S, Nakagawa K, Nakagawa K, Ikeura S, Etoh T (2001) Buzenkai niokeru you-yoshiebi no seitai nitsuite [Migration of young greasyback prawn (Metapenaeus ensis) in the Buzen Sea]. Bull Fukuoka Fish Mar Technol Res Cent 11: 11-16. (in Japanese)

Kochi District Fisheries Improvement Council, Kochi Prefectural Kochi Fisheries Guidance Office (1971) Tosawansan yoshiebi no seitai nitsuite [On the ecology of the greasyback shrimp in Tosa Bay]. Kochi District Fisheries Improvement Council, Kochi, 37 pp. (in Japanese)
Kusakabe T, Tsujino K, Abe T (1989) Oosakawan niokeru saruebi no taichou-sosei [Body length composition of the southern rough shrimp in Osaka Bay]. Rep Meet Inland Sea Fish Nansei Block 21: 13-18. (in Japanese)

Leung SF (1997) The population dynamics of Metapenaeus ensis (Crustacea: Decapoda: Penaeidae) in a traditional tidal shrimp pond at the Mai Po Marshes Nature Reserve, Hong Kong. J Zool Lond 242: 77-96.

Momoyama K, Hiraoka M, Inouye K, Kimura T, Nakano H, Yasui M (1997) Mass mortalities in the production of juvenile greasyback shrimp, Metapenaeus ensis, caused by penaeid acute viremia (PAV). Fish Pathol 32: 51-58.

Nakajima M, Yamamoto K, Tsujino K (2002) Senkai-teisenchousa [Monthly observation of water quality in Osaka Bay]. Ann Rep Osaka Pref Fish Exp Sta 2000: 1-18, (1)-(17). (in Japanese)

Ota S (1949) Nakaumi-shinjikosan yoshiebi (Metapenaeus monoceros) seitai-chousa [Ecological investigation on the greasyback shrimp (Metapenaeus monoceros) in Lake Nakaumi and Lake Shinji]. Invest Rep Fish Agen 18: 1-18. (in Japanese)

Park YC, Loneragan NR (1999) Effect of temperature on the behaviour of the endeavour prawns Metapenaeus endeavouri (Schmitt) and Metapenaeus ensis (De Haan) (Decapoda: Penaeidae). Mar Freshwater Res 50: 327-332.

Primavera JH (1997) Fish predation on mangrove-associated penaeids: the role of structures and substrate. J Exp Mar Biol Ecol 215: 205-216.

Primavera JH (1998) Mangroves as nurseries: shrimp populations in mangrove and non-mangrove habitats. Estuar Coast Shelf Sci 46: 457-464.

Robertson AI, Duke NC (1987) Mangroves as nursery sites: comparisons of the abundance and species composition of fish and crustaceans in mangroves and other nearshore habitats in tropical Australia. Mar Biol 96: 193-205.

Sakaji H, Komatsu A (2004) Growth and migration of the greasyback shrimp Metapenaeus ensis in Tosa Bay, southern Japan. Nippon Suisan Gakkaishi 70: 530-536. (in Japanese with English abstract)

Sheehy M, Cameron E, Marsden G, McGrath J (1995) Age structure of female giant tiger prawns Penaeus monodon as indicated by neuronal lipofuscin concentration. Mar Ecol Prog Ser 117: 59-63.

Staples DJ, Vance DJ, Heales DS (1985) Habitat requirements of juvenile penaeid prawns and their relationship to offshore fisheries. In: Second Australian National Prawn Seminar (eds Rothlisberg PC, Hill BJ, Staples DJ). CSIRO, Cleveland, pp. 47-54.

Su MS (1988) Some ecological considerations for stock enhancement of commercially important prawns along the coastal waters of southwest Taiwan. Acta Oceanographica Taiwanica 19: 145-165.

Su MS, Liao IC (1994) Ecological studies on commercially important prawns from the coastal waters of southwest Taiwan III Emigration of Metapenaeus ensis from Dapong Bay. J Fish Soc Taiwan 21: 183-195.

Tokuda M, Hamada H, Arie Y (1990) Yoshiebi-shubyouhouryuukouka ni kansuru kenkyuu-I. Shouwa-63-nendo 
houryuu-chousa [Studies on releasing effect of artificial larvae of the greasyback shrimp-I. Results in 1988]. Bull FukuokaBuzen Fish Exp Stat 3: 35-42. (in Japanese)

Tokuda M, Hamada H, Oda K (1991) Yoshiebi-shubyouhouryuukouka ni kansuru kenkyuu-II. 1989-nendo houryuuchousa [Studies on releasing effect of artificial larvae of the greasyback shrimp-II. Results in 1989]. Bull Fukuoka-Buzen Fish Exp Stat 4: 53-66. (in Japanese)

Tokuda M, Hamada T, Satou H (1997) Buzenkai niokeru yoshiebi no seijuku [The maturity of offshore greasyback prawn (Metapenaeus ensis) in Buzen Sea]. Bull Fukuoka Fish Mar Technol Res Cent 7: 9-14. (in Japanese)

Ueta Y, Ishida Y, Watanabe K, Hirosawa A, Mori K, Fukunaga M (1993) Kiisuidou niokeru kumaebi, yoshiebi, kurumaebi no seitai to gyogyou (chiiki-juuyoushigen) [Ecology and fishery of green tiger prawn, greasyback shrimp and Kuruma prawn in Kii Channel]. Ann Rep Tokushima Pref Fish Exp Stn 1991: 88-118. (in Japanese)

Viet TV, Sakuramoto K (2013) Population structure and fishing of the greasyback shrimp (Metapenaeus ensis, De Haan, 1844) by bag net in a coastal river of the Mekong Delta, Vietnam. Int J Fish Aquac 5: 83-91.

Yamochi S, Ariyama H, Sano M (1995) Occurrence and hypoxic tolerance of the juvenile Metapenaeus ensis at the mouth of the Yodo River, Japan. Fish Sci 61: 391-395.

Yasuda J (1956) Naiwan niokeru ebirui no shigenseibutsugakuteki-kenkyuu (II). Kakuron, kakushurui no seitai ni kansuru kenkyuu [Resource-biological study on the shrimps in an enclosed bay (II). Detailed exposition: study on the ecology of each species]. Bull Naikai Reg Fish Res Lab 9: 1-81. (in Japanese)

Yatuyanagi K, Maekawa K (1956) Yamaguchiken-setonaikai niokeru juuyouseibutsu no seitaigakuteki-kenkyuu. Dai-11-pou suounadasan-yoshiebi Metapenaeus monoceros F. no seitai [Ecological studies on the useful sea animals off Yamaguchi Pref., Inland Sea. 11. Ecological studies on the Yoshiebi, Metapenaeus monoceros FABRICIUS]. Invest Achiev Yamaguchi Pref Naikai Fish Exp Stat 8: 39-51. (in Japanese) 